Article

\title{
Catalytic steam reforming of rice straw biomass to hydrogen-rich syngas over Ni-based catalysts
}

\author{
LI Qingyuan, JI Shengfu*, HU Jinyong, JIANG Sai \\ State Key Laboratory of Chemical Resource Engineering, Beijing University of Chemical Technology, Beijing 100029, China
}

\section{A R T I C L E I N F O}

Article history:

Received 29 December 2012

Accepted 16 May 2013

Published 20 July 2013

Keywords:

Nickel-based catalyst

Rice straw

Steam reforming

Syngas

Hydrogen

\begin{abstract}
A B S T R A C T
Ni-based catalysts with $\mathrm{SiO}_{2}, \gamma-\mathrm{Al}_{2} \mathrm{O}_{3}, \mathrm{CaO}$, and $\mathrm{TiO}_{2}$ as supports and $\mathrm{MgO}-7.5 \% \mathrm{Ni} / \gamma-\mathrm{Al}_{2} \mathrm{O}_{3}$ catalysts with different contents of $\mathrm{MgO}$ were prepared. The structure of the catalysts was characterized by powder X-ray diffraction and $\mathrm{N}_{2}$ adsorption-desorption measurements. The performance of the catalysts in the steam reforming of rice straw biomass to syngas was evaluated. The effects of reaction conditions on the activity of the catalysts were also investigated. Ni-based catalysts supported on $\gamma-\mathrm{Al}_{2} \mathrm{O}_{3}$ had higher catalytic activity than the catalysts supported on $\mathrm{TiO}_{2}, \mathrm{CaO}$, and $\mathrm{SiO}_{2}$. The yield of $\mathrm{H}_{2}$ reached $1071.3 \mathrm{ml} \mathrm{H} / 2$ g biomass and the ratio of $\mathrm{H}_{2}$ to $\mathrm{CO}$ was $1.4: 1$ over a $7.5 \% \mathrm{Ni} / \gamma-\mathrm{Al}_{2} \mathrm{O}_{3}$ catalyst. Addition of $\mathrm{MgO}$ to the $7.5 \% \mathrm{Ni} / \gamma-\mathrm{Al}_{2} \mathrm{O}_{3}$ catalyst improved its catalytic activity. The yield of $\mathrm{H}_{2}$ reached $1194.6 \mathrm{ml} \mathrm{H}_{2} / \mathrm{g}$ biomass and the ratio of $\mathrm{H}_{2}$ to $\mathrm{CO}$ was $3.9: 1$ over the $1.0 \% \mathrm{MgO}-7.5 \%$ $\mathrm{Ni} / \gamma-\mathrm{Al}_{2} \mathrm{O}_{3}$ catalyst. $\mathrm{MgO}$ not only improves the steam reforming reaction of $\mathrm{Ni}$-based catalysts, but can also promote the water-gas shift reaction. This method shows promise for production of $\mathrm{H}_{2}$-rich syngas from biomass.
\end{abstract}

(C) 2013, Dalian Institute of Chemical Physics, Chinese Academy of Sciences. Published by Elsevier B.V. All rights reserved.

\section{Introduction}

China is a large agricultural country, so the biomass resources, e.g., straw and crop residues, available for energy use are abundant. China produces more than 640 million tons of straw per year, and its production will increase as the crop yield is improved. Straw is mainly used as a fertilizer, feed and for burning in traditional agriculture [1]. Effective use of biomass energy is needed to solve agricultural, energy, and environmental protection problems. An effective way to use straw involves thermal cracking, gasification, and catalytic conversion of straw resources to produce syngas and $\mathrm{H}_{2}$. This process is environmentally friendly and produces energy efficiently.

The main products from pyrolysis and gasification of biomass are $\mathrm{CO}, \mathrm{H}_{2}$, and other hydrocarbons, of which about
$30 \%-50 \%$ is CO $[2,3]$. Unfortunately, gas produced from this process usually contains too much $\mathrm{CO}$ and unacceptable levels of tar for intended applications. Tar can foul equipment such as engines and turbines during the condensation process [4]. Pyrolysis and gasification with steam is a process that can greatly decrease the yield of tar from biomass. Corella et al. [5] recognized that steam is a more effective gasifying agent for tar removal than oxygen or a mixture of oxygen and steam under the same conditions. Moreover, $\mathrm{H}_{2}$ yields can be enhanced by using steam as gasifying agent over other gases.

Catalytic reforming of biomass, which can convert biomass into syngas with little tar at relatively low reaction temperature, has received wide attention recently. Rapagna et al. [6] used several kinds of catalysts in catalytic reforming of biomass for $\mathrm{H}_{2}$ production, including mineral resources such as dolo-

\footnotetext{
* Corresponding author. Tel/Fax: +86-10-64419619; E-mail: jisf@mail.buct.edu.cn This work was supported by the National Basic Research Program of China (973 Program, 2005CB221405) and the National High Technology Research and Development Program of China (863 Program, 2006AA10Z425). DOI: 10.1016/S1872-2067(12)60618-4 | http://www.sciencedirect.com/science/journal/18722067 | Chin. J. Catal., Vol. 34,No. 7, July 2013
} 
mite, magnesite, zeolite, and olivine, as well as Ni-based and noble metal catalysts. Dolomite is the most commonly used catalyst of this group because it is cheap and has a tar removal function. Despite its high catalytic activity, dolomite has some disadvantages such as low mechanical strength, which restricts its further application [7]. Ni-based catalysts have been used extensively for gasification, tar conversion, and reforming light hydrocarbons because of their high tar destruction activity and ability to improve the content of syngas in the produced gas [8-13]. However, the rapid deactivation of Ni-based catalysts by carbon deposition and sintering of active Ni particles seriously impede their application. For these reasons, many novel catalysts have been developed for gasification of biomass.

Wang et al. [14] investigated biomass air-steam gasification in a bubbling bed biomass gasifier with $\mathrm{NiO}-\mathrm{MgO}$ as a catalyst. They found that their NiO-MgO catalyst showed better catalytic activity and anti-coke ability at high temperature $\left(>750{ }^{\circ} \mathrm{C}\right)$ than a commercial Ni-based reforming catalyst. Nakamura et al. [15] reported that adding $\mathrm{MgO}$ to $\mathrm{Pt} / \mathrm{Ni} / \mathrm{CeO}_{2} / \mathrm{Al}_{2} \mathrm{O}_{3}$ promoted the steam gasification of biomass. The addition of $\mathrm{MgO}$ decreased the degree of reduction of $\mathrm{Ni}$ but increased the dispersion of $\mathrm{Ni}$ metal particles. Their $\mathrm{Pt} / \mathrm{Ni} / \mathrm{CeO}_{2} / \mathrm{MgO} / \mathrm{Al}_{2} \mathrm{O}_{3}$ catalyst exhibited high resistance to aggregation, which resulted in high stability. Jiang and coworkers [16] studied the pyrolysis and gasification of small particles of biomass, such as rice or wheat straw and sawdust, in a fluidized bed. They found that the gasification of rice straw produced more $\mathrm{H}_{2}$ than the other types of biomass investigated, and addition of $\mathrm{Na}_{2} \mathrm{CO}_{3}$ simultaneously enhanced the content of $\mathrm{H}_{2}$ and decreased the content of CO. Umeki et al. [17] investigated pyrolysis and char reaction behavior during rice straw gasification in detail to clarify the effect of steam. The difference of $\mathrm{H}_{2}$ yield using steam versus an inert atmosphere was about twice the $\mathrm{CO}_{2}$ yield using a steam atmosphere. This is because the water-gas shift reaction was accelerated by the catalytic behavior of char and excess steam available.

Recently, we prepared Ni-based catalysts for catalytic steam reforming of poplar leaves and found that $\mathrm{Ni}$ as the active component of the catalysts exhibited good activity for this reaction [18]. Our catalysts were also effective for tar conversion. In this study, a series of Ni-based catalysts with $\mathrm{TiO}_{2}, \mathrm{CaO}, \mathrm{SiO}_{2}$, and $\gamma-\mathrm{Al}_{2} \mathrm{O}_{3}$ as supports and $\mathrm{MgO}-7.5 \% \mathrm{Ni} / \gamma-\mathrm{Al}_{2} \mathrm{O}_{3}$ catalysts with different contents of $\mathrm{MgO}$ are prepared. The performance of the catalysts for conversion of rice straw to syngas in a fixed-bed reactor is investigated. The influence of $\mathrm{Ni}$ and $\mathrm{MgO}$ contents in the catalysts, reaction temperature, steam/biomass ratio, and biomass/catalyst mass ratio on the steam reforming of rice straw to $\mathrm{H}_{2}$-rich syngas are studied in detail.

\section{Experimental}

\subsection{Catalyst preparation}

The catalysts in this study were prepared by an incipient wetness impregnation method. An appropriate amount of $\gamma-\mathrm{Al}_{2} \mathrm{O}_{3}$ (Shangdong Aluminum Co., China), $\mathrm{TiO}_{2}$ (Tianjin Damao Chemical Reagents Factory, China), $\mathrm{SiO}_{2}$ (Qingdao Defeng
Chemical Industrial Co., China), or CaO (Tianjin Fuchen Chemical Reagents Factory, China) was added to an aqueous solution of $\mathrm{Ni}\left(\mathrm{NO}_{3}\right)_{2}$ (Beijing Yili Fine Chemical Co., Ltd.). Each mixture was stirred to form a uniform slurry and then left undisturbed at room temperature overnight. The samples were dried at 110 ${ }^{\circ} \mathrm{C}$ for $12 \mathrm{~h}$ and then calcined at $550{ }^{\circ} \mathrm{C}$ for $5 \mathrm{~h}$ in air to give 7.5 wt $\%$ Ni-based catalysts on different supports. The same method was used to prepare $\mathrm{Ni} / \gamma-\mathrm{Al}_{2} \mathrm{O}_{3}$ catalysts with $\mathrm{Ni}$ contents ranging from $2.5 \mathrm{wt} \%$ to $15 \mathrm{wt} \%$. $\mathrm{MgO}-7.5 \% \mathrm{Ni} / \gamma-\mathrm{Al}_{2} \mathrm{O}_{3}$ catalysts with MgO loadings of 0.5 wt $\%-2.0$ wt $\%$ were also prepared by incipient wetness impregnation. First, a $\mathrm{Ni} / \gamma-\mathrm{Al}_{2} \mathrm{O}_{3}$ precursor with a Ni loading of $7.5 \mathrm{wt} \%$ was prepared. The precursor was then impregnated with $\mathrm{Mg}\left(\mathrm{NO}_{3}\right)_{2}$ solution. Finally, the catalyst was dried at $100{ }^{\circ} \mathrm{C}$ overnight and calcined at 550 ${ }^{\circ} \mathrm{C}$ for $5 \mathrm{~h}$ in air.

\subsection{Catalyst characterization}

The phase structures of the samples were characterized by powder X-ray diffraction (XRD) using a Rigaku D/Max 2500 $\mathrm{VB} 2+/ \mathrm{PC}$ diffractometer, with $\mathrm{Cu} K_{\alpha}$ radiation operating at 40 $\mathrm{mA}$ and $40 \mathrm{kV}$. The specific surface area, pore volume, and pore size distribution of the catalysts were characterized using a Quadrasorb SI analyzer. Prior to adsorption, the samples were degassed at $300{ }^{\circ} \mathrm{C}$ for $2 \mathrm{~h}$ to remove physically adsorbed components. Specific surface areas were calculated using the BET equation. Pore volume and pore size distribution were determined by the BJH method.

\subsection{Elemental analysis}

The contents of $\mathrm{C}, \mathrm{H}, \mathrm{N}$, and $\mathrm{O}$ in the catalysts were analyzed using a CHNS/O analyzer. The ash, moisture, and volatile matter contents of the catalysts were analyzed by a muffle furnace using the proximate analysis method of coal. The content of fixed $\mathrm{C}$ was calculated by difference. The results of the above analysis for rice straw are presented in Table 1.

\subsection{Catalytic activity}

Rice straw was collected from the countryside of Huanggang, Hubei, China. Before reaction, the rice straw was dried naturally in the sun, crushed to 40-60 mesh powder using a ball mill, and then dried at $50{ }^{\circ} \mathrm{C}$ in an oven until its mass was constant.

Figure 1 shows a schematic diagram of the experimental apparatus for steam reforming of rice straw, which consisted of a fixed-bed continuous flow quartz reactor, steam generator, steam/gas feed line, condensing units, and measure-

Table 1

Proximate and ultimate analyses of rice straw.

\begin{tabular}{lccc}
\hline $\begin{array}{l}\text { Proximate } \\
\text { analysis }\end{array}$ & $\begin{array}{c}\text { Content } \\
(\%)\end{array}$ & $\begin{array}{c}\text { Ultimate } \\
\text { analysis }\end{array}$ & $\begin{array}{c}\text { Content } \\
(\%, \text { dry basis })\end{array}$ \\
\hline Volatile matter & 67.82 & $\mathrm{C}$ & 41.56 \\
Fixed carbon & 13.40 & $\mathrm{H}$ & 1.06 \\
Moisture & 7.26 & $\mathrm{O}$ & 37.48 \\
Ash & 11.52 & $\mathrm{~N}$ & 1.11 \\
\hline
\end{tabular}




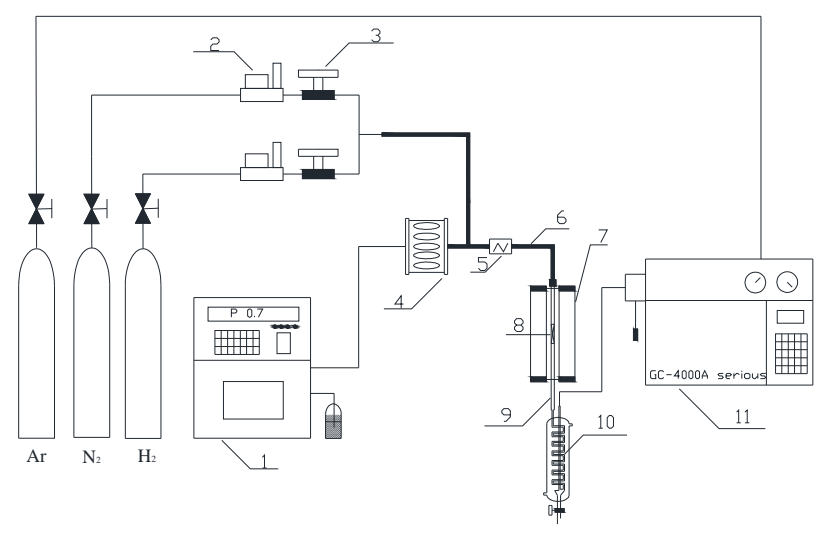

Fig. 1. Schematic diagram of the equipment for steam reforming of rice straw. (1) Plunger pump; (2) Mass flow meter; (3) Valve; (4) Evaporator; (5) Mixer; (6) Heating belt; (7) Furnace; (8) Reactant bed; (9) Quartz reactor; (10) Cold trap; (11) Gas chromatograph.

ment/analysis devices.

Prior to reaction, the catalyst was reduced with $\mathrm{H}_{2}$ (10 $\mathrm{ml} / \mathrm{min}$ ) at $700{ }^{\circ} \mathrm{C}$ for $3 \mathrm{~h}$. Then, the rice straw powder and catalyst were mixed sufficiently and packed into the reactor. When the reaction temperature was reached under $\mathrm{N}_{2}$, steam was immediately introduced into the reactor and the reforming of rice straw biomass began. Gas products were collected from the outlet and analyzed by an online gas chromatograph (Beijing East \& West Electronics Institute, GC-4000 A) with a TDX-01 column and a TCD detector. The gas products such as $\mathrm{CO}, \mathrm{H}_{2}$, and $\mathrm{CO}_{2}$ were calculated by the area normalization method using $\mathrm{N}_{2}(10 \mathrm{ml} / \mathrm{min})$ as an internal standard. The yield of $\mathrm{H}_{2}$ was calculated by integration until no $\mathrm{H}_{2}$ was detected. The reaction lasted for nearly $5 \mathrm{~h}$, during which time the catalysts remained stable. $\mathrm{CH}_{4}$ and tar were not detected during the reaction. After reaction, the biomass residue was cooled to room temperature under $\mathrm{N}_{2}$ protection and the catalyst was removed.

\section{Results and discussion}

\subsection{Structure and catalytic activity of Ni-based catalysts with different supports}

Figure 2 shows the XRD patterns of the catalysts with 7.5 wt\% $\mathrm{Ni}$ supported on $\mathrm{SiO}_{2}, \gamma-\mathrm{Al}_{2} \mathrm{O}_{3}, \mathrm{CaO}$, and $\mathrm{TiO}_{2}$. Broad peaks consistent with $\mathrm{NiO}$ were observed over $7.5 \% \mathrm{Ni} / \mathrm{SiO}_{2}$. This indicates that the $\mathrm{NiO}$ grains were smaller on the $\mathrm{SiO}_{2}$ support than in the other catalysts. However, peaks from $\mathrm{NiO}$ were not observed for $7.5 \% \mathrm{Ni} / \gamma-\mathrm{Al}_{2} \mathrm{O}_{3}$. This is attributed to the high dispersion of $\mathrm{NiO}$ on the $\gamma-\mathrm{Al}_{2} \mathrm{O}_{3}$ support. Relatively sharp peaks of $\mathrm{NiO}$ were observed over $7.5 \% \mathrm{Ni} / \mathrm{CaO}$ and $7.5 \%$ $\mathrm{Ni} / \mathrm{TiO}_{2}$, indicating that the $\mathrm{NiO}$ grains were larger on the $\mathrm{CaO}$ and $\mathrm{TiO}_{2}$ supports than $\mathrm{SiO}_{2}$.

Table 2 shows the catalytic activity of the Ni-based catalysts with $\mathrm{SiO}_{2}, \gamma-\mathrm{Al}_{2} \mathrm{O}_{3}, \mathrm{CaO}$, and $\mathrm{TiO}_{2}$ supports for the steam reforming of rice straw to syngas. The activity of the catalysts depended on the support. Among the four catalysts, $7.5 \%$ $\mathrm{Ni} / \mathrm{CaO}$ showed the lowest yield of $\mathrm{H}_{2}$ of just $792.0 \mathrm{ml} / \mathrm{g}$. The

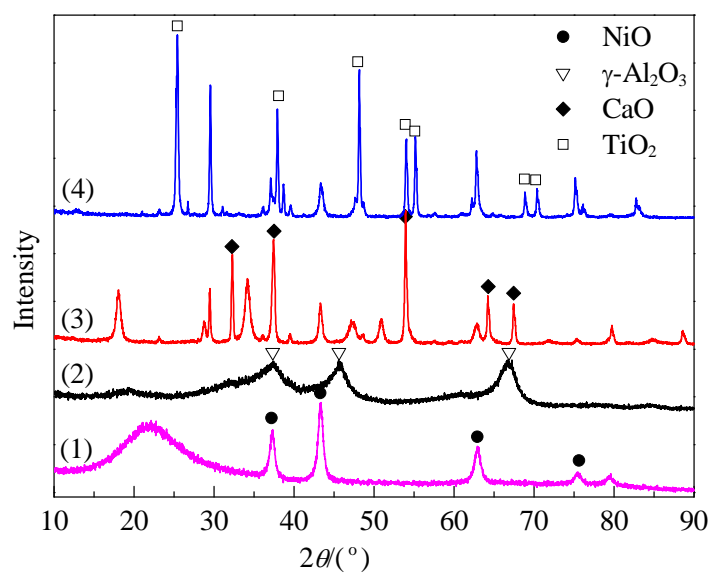

Fig. 2. XRD patterns of different Ni-based catalysts with different supports. (1) $7.5 \% \mathrm{Ni} / \mathrm{SiO}_{2}$; (2) $7.5 \% \mathrm{Ni} / \gamma-\mathrm{Al}_{2} \mathrm{O}_{3}$; (3) $7.5 \% \mathrm{Ni} / \mathrm{CaO}$; (4) $7.5 \% \mathrm{Ni} / \mathrm{TiO}_{2}$.

$7.5 \% \mathrm{Ni} / \gamma-\mathrm{Al}_{2} \mathrm{O}_{3}$ catalyst gave the highest yield of $\mathrm{H}_{2}$, reaching $1071.3 \mathrm{ml} / \mathrm{g}$. This could mainly due to the surface acidity of the $\gamma-\mathrm{Al}_{2} \mathrm{O}_{3}$ support that can promote the tar cracking reaction. In addition, the interaction between $\gamma-\mathrm{Al}_{2} \mathrm{O}_{3}$ and $\mathrm{Ni}$ benefited endothermic reforming reactions and enhanced production of $\mathrm{H}_{2}$ $[19,20]$. As a result, we decided to focus on the structure and catalytic activity of $\mathrm{Ni} / \gamma-\mathrm{Al}_{2} \mathrm{O}_{3}$ catalysts with different $\mathrm{Ni}$ contents.

Table 2 also shows that $765.2 \mathrm{ml} / \mathrm{g}$ of $\mathrm{CO}$ is obtained over a $7.5 \% \mathrm{Ni} / \gamma-\mathrm{Al}_{2} \mathrm{O}_{3}$ catalyst. This value is consistent with the results obtained from elemental analysis, which gave $775.8 \mathrm{ml} / \mathrm{g}$ of CO.

\subsection{Structure and catalytic activity of $\mathrm{Ni} / \gamma-\mathrm{Al}_{2} \mathrm{O}_{3}$ catalysts with different Ni contents}

XRD patterns of the $\mathrm{Ni} / \gamma-\mathrm{Al}_{2} \mathrm{O}_{3}$ catalysts with different $\mathrm{Ni}$ contents and $7.5 \% \mathrm{Ni} / \gamma-\mathrm{Al}_{2} \mathrm{O}_{3}$ catalysts reduced at $700{ }^{\circ} \mathrm{C}$ for 3 $\mathrm{h}$ are depicted in Fig. 3. The main diffraction peaks found at $2 \theta$ $=37.2^{\circ}, 46.1^{\circ}$, and $66.7^{\circ}$ could be assigned to $\gamma-\mathrm{Al}_{2} \mathrm{O}_{3}$. NiO diffraction peaks were not found for the $7.5 \% \mathrm{Ni} / \gamma-\mathrm{Al}_{2} \mathrm{O}_{3}$ catalysts probably because of the low content and high dispersion of $\mathrm{NiO}$ particles. As the Ni content increased, the intensity of Ni peaks increased correspondingly. The $12.5 \% \mathrm{Ni} / \gamma-\mathrm{Al}_{2} \mathrm{O}_{3}$ and $15.0 \%$ $\mathrm{Ni} / \gamma-\mathrm{Al}_{2} \mathrm{O}_{3}$ catalysts had weak diffraction peaks from $\mathrm{NiO}$ near $2 \theta=43.3^{\circ}$ and $62.9^{\circ}$, indicating that some of the NiO particles aggregated in these catalysts. Strong, sharp diffraction peaks at $2 \theta=44.5^{\circ}, 51.8^{\circ}$, and $76.3^{\circ}$ for $7.5 \% \mathrm{Ni} / \gamma-\mathrm{Al}_{2} \mathrm{O}_{3}$ following re-

\section{Table 2}

Gas products formed over Ni-based catalysts with different supports.

\begin{tabular}{|c|c|c|c|c|}
\hline \multirow{2}{*}{ Catalyst } & \multicolumn{2}{|c|}{ Volume contents (\%) } & \multirow{2}{*}{$\begin{array}{c}\mathrm{H}_{2} / \mathrm{CO} \\
\text { ratio }\end{array}$} & \multirow{2}{*}{$\begin{array}{c}\mathrm{H}_{2} \text { yield a } \\
(\mathrm{ml} / \mathrm{g})\end{array}$} \\
\hline & $\mathrm{H}_{2}$ & $\mathrm{CO}$ & & \\
\hline $7.5 \% \mathrm{Ni} / \mathrm{SiO}_{2}$ & 28.6 & 21.4 & 1.3 & 961.3 \\
\hline $7.5 \% \mathrm{Ni} / \gamma-\mathrm{Al}_{2} \mathrm{O}_{3}$ & 33.1 & 23.2 & 1.4 & 1071.3 \\
\hline $7.5 \% \mathrm{Ni} / \mathrm{CaO}$ & 25.6 & 21.9 & 1.2 & 792.0 \\
\hline $7.5 \% \mathrm{Ni} / \mathrm{TiO}_{2}$ & 28.1 & 28.2 & 1.0 & 847.0 \\
\hline
\end{tabular}

Reaction conditions: $T=820^{\circ} \mathrm{C}$, steam/biomass $=2.02$, mass of biomass $=0.2 \mathrm{~g}$, biomass $/$ catalyst $=5 / 1$.

a Volume of $\mathrm{H}_{2}$ produced per gram of biomass. 


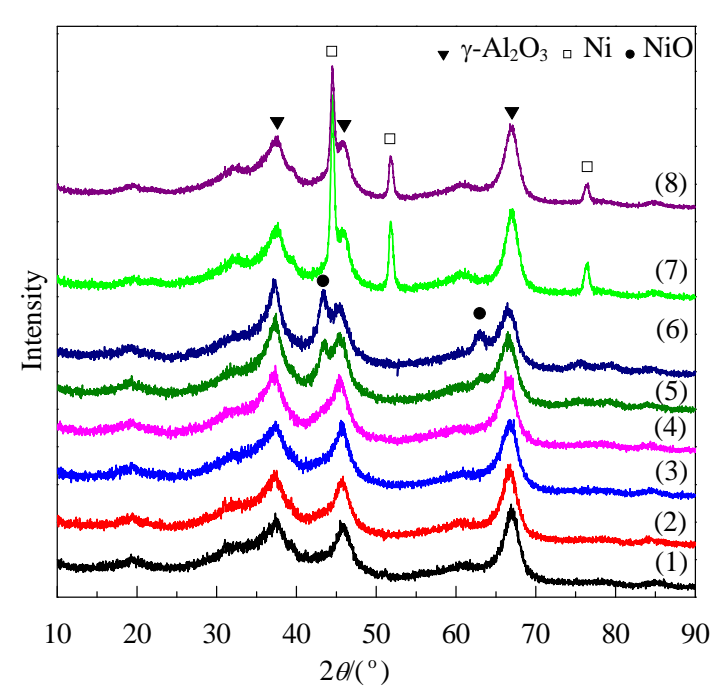

Fig. 3. XRD patterns of $\mathrm{Ni} / \gamma-\mathrm{Al}_{2} \mathrm{O}_{3}$ catalysts with different $\mathrm{Ni}$ contents. (1) $2.5 \%$; (2) $5.0 \%$; (3) 7.5\%; (4) 10.0\%; (5) 12.5\%; (6) 15.0\%; (7) The catalyst in (3) reduced at $700{ }^{\circ} \mathrm{C}$ for $3 \mathrm{~h}$; (8) The catalysts in (7) after $5 \mathrm{~h}$ reaction.

duction in $\mathrm{H}_{2}$ at $700{ }^{\circ} \mathrm{C}$ for $3 \mathrm{~h}$ revealed that large $\mathrm{Ni}^{0}$ particles had formed [21].

After the reforming reaction, the catalyst still exhibited diffraction peaks from $\mathrm{Ni}^{0}$ particles. This means that the active component of the catalyst retained its structure and activity after $5 \mathrm{~h}$, which is consistent with previous publications $[22,23]$. The XRD pattern of the used catalyst was similar to that of $7.5 \% \mathrm{Ni} / \gamma-\mathrm{Al}_{2} \mathrm{O}_{3}$ reduced in $\mathrm{H}_{2}$ at $700{ }^{\circ} \mathrm{C}$ for $3 \mathrm{~h}$, further indicating the stability of the catalyst. According to the Scherrer equation, the size of $\mathrm{Ni}^{0}$ particles before and after reaction was 2.6 and $3.2 \mathrm{~nm}$, respectively. Therefore, the $\mathrm{Ni}^{0}$ grains increased in size during the reforming reaction.

The specific surface area and pore size distribution of the samples are shown in Table 3. As the Ni loading increased, the specific surface area and pore volume of the catalysts decreased gradually, whereas the average pore diameter first increased. This can be attributed to the aggregation of Ni active component $[24,25]$. In fact, two pore sizes were found for the catalysts with higher Ni loading: around 3.8 and $4.9 \mathrm{~nm}$. At a suitable Ni loading, the main pore size was $4.9 \mathrm{~nm}$. However, when the Ni loading was excessive, the aggregation of Ni active component increased, and the main pore size of the catalysts decreased to $3.8 \mathrm{~nm}$.

The effect of $\mathrm{Ni}$ content within the range from $2.5 \%$ to $15.0 \%$ was studied, and the results are listed in Table 4 . As the $\mathrm{Ni}$ content increased, the $\mathrm{H}_{2}$ yield exhibited an optimum value.

Table 3

Pore structure parameters of different $\mathrm{Ni} / \gamma-\mathrm{Al}_{2} \mathrm{O}_{3}$ catalysts.

\begin{tabular}{lccc}
\hline Catalyst & $\begin{array}{c}A_{\text {BET }} \\
\left(\mathrm{m}^{2} / \mathrm{g}\right)\end{array}$ & $\begin{array}{c}\text { Pore volume } \\
\left(\mathrm{cm}^{3} / \mathrm{g}\right)\end{array}$ & $\begin{array}{c}\text { Mean pore size } \\
(\mathrm{nm})\end{array}$ \\
\hline $2.5 \% \mathrm{Ni} / \gamma-\mathrm{Al}_{2} \mathrm{O}_{3}$ & 232.3 & 0.44 & 3.8 \\
$5.0 \% \mathrm{Ni} / \gamma-\mathrm{Al}_{2} \mathrm{O}_{3}$ & 204.2 & 0.41 & 3.8 \\
$7.5 \% \mathrm{Ni} / \gamma-\mathrm{Al}_{2} \mathrm{O}_{3}$ & 200.9 & 0.37 & 4.9 \\
$10.0 \% \mathrm{Ni} / \gamma-\mathrm{Al}_{2} \mathrm{O}_{3}$ & 175.2 & 0.37 & 5.0 \\
$12.5 \% \mathrm{Ni} / \gamma-\mathrm{Al}_{2} \mathrm{O}_{3}$ & 168.1 & 0.34 & 3.8 \\
$15.0 \% \mathrm{Ni} / \gamma-\mathrm{Al}_{2} \mathrm{O}_{3}$ & 166.8 & 0.34 & 3.9 \\
\hline
\end{tabular}

Table 4

Gas products and $\mathrm{H}_{2}$ yield over $\mathrm{Ni} / \gamma-\mathrm{Al}_{2} \mathrm{O}_{3}$ catalysts.

\begin{tabular}{|c|c|c|c|c|}
\hline \multirow{2}{*}{ Catalyst } & \multicolumn{2}{|c|}{ Volume contents (\%) } & \multirow{2}{*}{$\begin{array}{l}\mathrm{H}_{2} / \mathrm{CO} \\
\text { ratio } \\
\end{array}$} & \multirow{2}{*}{$\begin{array}{l}\mathrm{H}_{2} \text { yield } \\
(\mathrm{ml} / \mathrm{g})\end{array}$} \\
\hline & $\mathrm{H}_{2}$ & $\mathrm{CO}$ & & \\
\hline $2.5 \% \mathrm{Ni} / \gamma-\mathrm{Al}_{2} \mathrm{O}_{3}$ & 28.5 & 20.3 & 1.4 & 815.2 \\
\hline $5.0 \% \mathrm{Ni} / \gamma-\mathrm{Al}_{2} \mathrm{O}_{3}$ & 30.3 & 21.9 & 1.4 & 1027.1 \\
\hline $7.5 \% \mathrm{Ni} / \gamma-\mathrm{Al}_{2} \mathrm{O}_{3}$ & 33.1 & 23.2 & 1.4 & 1071.3 \\
\hline $10.0 \% \mathrm{Ni} / \gamma-\mathrm{Al}_{2} \mathrm{O}_{3}$ & 32.9 & 22.9 & 1.4 & 1036.9 \\
\hline $12.5 \% \mathrm{Ni} / \gamma-\mathrm{Al}_{2} \mathrm{O}_{3}$ & 30.1 & 22.7 & 1.3 & 1032.4 \\
\hline $15.0 \% \mathrm{Ni} / \gamma-\mathrm{Al}_{2} \mathrm{O}_{3}$ & 28.4 & 20.0 & 1.4 & 1005.6 \\
\hline
\end{tabular}

Reaction conditions: $T=820^{\circ} \mathrm{C}$, steam $/$ biomass $=2.02$, biomass mass $=$ $0.2 \mathrm{~g}$, biomass $/$ catalyst $=5 / 1$.

This means the Ni content reached a saturation point. From Table 4 , as the Ni content increased from $2.5 \%$ to $7.5 \%$, the volume content of $\mathrm{H}_{2}$ and $\mathrm{CO}$ increased by $16 \%$ and $14 \%$, respectively. Simultaneously, the $\mathrm{H}_{2}$ yield was increased by $31 \%$ and reached $1071.3 \mathrm{ml} / \mathrm{g}$. After this point, the $\mathrm{H}_{2}$ yield did not increase any further with Ni content. This agrees with the conclusions of a previous publication [26]. In our study, the optimum $\mathrm{H}_{2}$ yield was achieved when the $\mathrm{Ni}$ content was $7.5 \%$. Beyond this value, the $\mathrm{H}_{2}$ yield and $\mathrm{CO}$ content reduced slightly as the $\mathrm{Ni}$ content increased. It was noteworthy that the ratio of $\mathrm{H}_{2}$ to $\mathrm{CO}$ was constant as the Ni content increased. From the $\mathrm{H}_{2} / \mathrm{CO}$ ratio and $\mathrm{H}_{2}$ yield, the theoretical C content is $40.98 \%$, which was consistent with the elemental analysis data in Table 1.

Besides the influence of $\mathrm{Ni}$ content, reaction temperature was also an important factor, as shown in Fig. 4. As the temperature increased, the volume content and yield of $\mathrm{H}_{2}$ increased obviously, reaching $34.2 \%$ and $1135.9 \mathrm{ml} / \mathrm{g}$ at $830{ }^{\circ} \mathrm{C}$, respectively. Moreover, the volume content of syngas increased from $48.4 \%$ to $59.9 \%$ when the temperature rose from 810 to 830 ${ }^{\circ} \mathrm{C}$. However, the ratio of $\mathrm{H}_{2}$ to $\mathrm{CO}$ decreased from 1.60 to 1.33. Thus, increasing temperature did not always benefit the production of $\mathrm{H}_{2}$-rich syngas.

The large increase of gas yield as the steam reforming temperature increased may be caused by three processes: (1) more unconverted volatile species were released with increasing temperature, (2) steam cracking and reforming of tar, which increases with temperature, and (3) endothermic reactions of char gasification, which favors higher temperatures. An in-

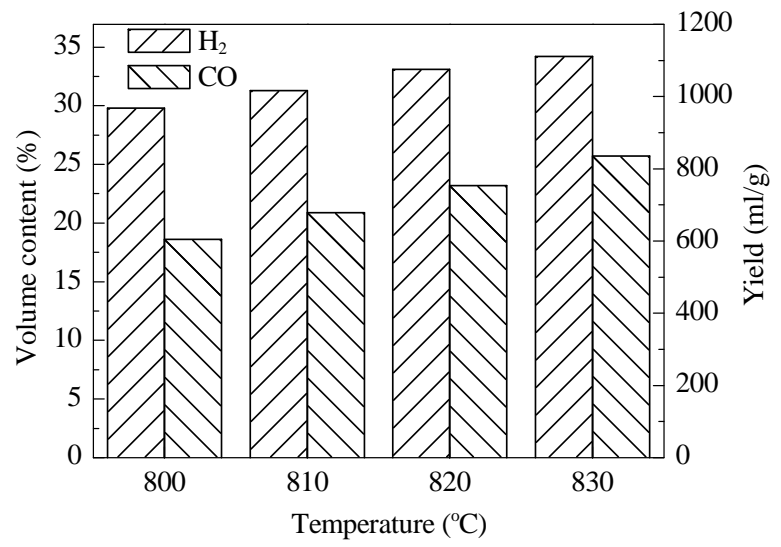

Fig. 4. The distribution and yields of gas products $\mathrm{H}_{2}$ and $\mathrm{CO}$ at different temperatures over $7.5 \% \mathrm{Ni} / \gamma-\mathrm{Al}_{2} \mathrm{O}_{3}$ catalysts. Reaction conditions: steam $/$ biomass $=2.02$, biomass mass $=0.2 \mathrm{~g}$, biomass $/$ catalyst $=5 / 1$. 
Table 5

Gas products and $\mathrm{H}_{2}$ yield for different steam to biomass ratios over $7.5 \% \mathrm{Ni} / \gamma-\mathrm{Al}_{2} \mathrm{O}_{3}$ catalysts.

\begin{tabular}{lcccr}
\hline \multirow{2}{*}{$\begin{array}{l}\text { Stream/biomass } \\
\text { ratio }\end{array}$} & \multicolumn{2}{c}{ Volume contents (\%) } & \multirow{2}{*}{$\begin{array}{c}\mathrm{H}_{2} / \mathrm{CO} \\
\text { ratio }\end{array}$} & $\begin{array}{r}\mathrm{H}_{2} \text { yield } \\
\text { (ml/g) }\end{array}$ \\
\cline { 2 - 3 } 0.81 & 20.1 & 27.4 & 0.73 & 789.6 \\
1.35 & 26.4 & 25.7 & 1.03 & 973.5 \\
2.02 & 33.1 & 23.2 & 1.43 & 1071.3 \\
3.40 & 38.8 & 16.7 & 2.32 & 1128.7 \\
\hline
\end{tabular}

Reaction conditions: $T=820^{\circ} \mathrm{C}$, biomass mass $=0.2 \mathrm{~g}$, biomass/catalyst $=5 / 1$.

crease of temperature has different affects on different components of the gas product. When the steam reforming temperature exceeded $800{ }^{\circ} \mathrm{C}$, a large decrease of $\mathrm{CO}_{2}$ and $\mathrm{CH}_{4}$ and an increase of $\mathrm{CO}$ were observed with rising temperature, illustrating that the water-gas and methane steam reforming reactions played dominant roles to the water-gas shift reaction [27]. An increase of temperature disfavors the exothermic water-gas shift reaction, which affects the $\mathrm{H}_{2}$ yield and volume content of gas product. The increase of $\mathrm{CO}$ volume content was faster than that of $\mathrm{H}_{2}$ volume content, so the $\mathrm{H}_{2} / \mathrm{CO}$ ratio decreased, as shown in Fig. 4.

Steam is a feasible reforming agent that is also used to promote reforming of tar, hydrocarbons and the water-gas shift reaction in this study. As shown in Table 5, with the increase of steam, the $\mathrm{H}_{2}$ yield, $\mathrm{H}_{2}$ volume fraction, and $\mathrm{H}_{2} / \mathrm{CO}$ ratio increased gradually, whereas the $\mathrm{CO}$ content decreased. This is because more $\mathrm{CO}, \mathrm{CH}_{4}$, and $\mathrm{C}_{n} \mathrm{H}_{m}$ take part in the steam reforming reaction as the steam rate is increased.

It is notable that $\mathrm{CO}$ can be generated by three possible reaction pathways during steam reforming of rice straw: from the primary pyrolysis of rice straw, from the secondary pyrolysis in the solid or gas phase, and the steam reforming of tar [28-30]. Under the studied reaction temperatures, $\mathrm{CO}$ is mainly generated from secondary pyrolysis. Thus, the slight decrease of $\mathrm{CO}$ by steam possibly indicates incomplete steam reforming of the gas phase.

As the steam/biomass ratio increased, the $\mathrm{H}_{2} / \mathrm{CO}$ ratio also increased and more syngas was generated. Thus, by controlling the input of steam, the $\mathrm{H}_{2} / \mathrm{CO}$ ratio in the syngas formed during steam gasification of biomass can be adjusted to a desired value. Syngas with an $\mathrm{H}_{2} / \mathrm{CO}$ molar ratio in the higher range is desirable for producing $\mathrm{H}_{2}$ for ammonia synthesis and can also be used to produce pure $\mathrm{H}_{2}$ for fuel cell applications [31]. Although a higher steam/biomass ratio is favorable for higher gas yields, it requires more external heat (from an external heater) or working at a low temperature [20], which is one of the most important factors considered in this study. As a result, we chose 2.02 as the optimum steam/biomass ratio for this reaction.

Figure 5 shows the effect of biomass/catalyst ratio on the yields of $\mathrm{H}_{2}$ and $\mathrm{CO}$. It shows that the maximum $\mathrm{H}_{2}$ yield and volume content of syngas were reached at a biomass/catalyst ratio of 5:1 for biomass/catalyst. Compared with the $\mathrm{H}_{2}$ yield and volume content, the ratio of $\mathrm{H}_{2} / \mathrm{CO}$ was nearly constant. In other words, the composition of syngas was hardly affected by the biomass/catalyst ratio. From the above, we can conclude that the introduction of excessive catalyst into the reactor is

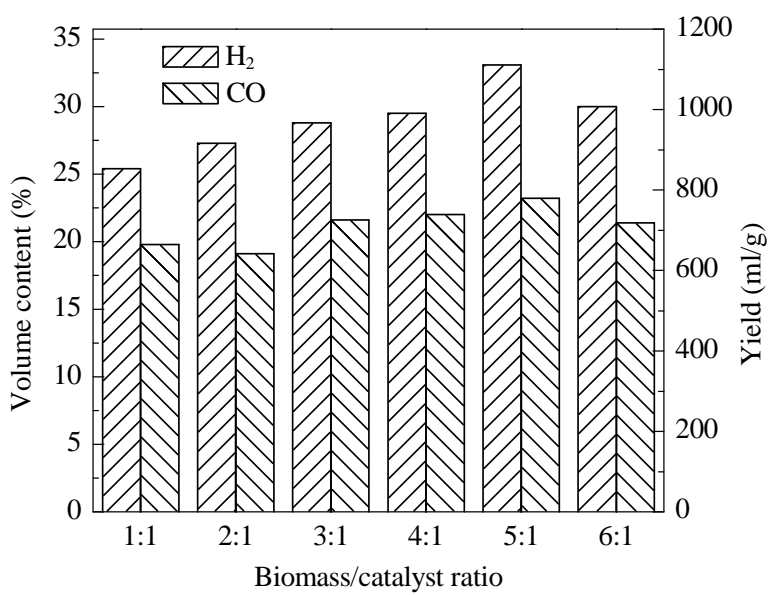

Fig. 5. Yields of $\mathrm{H}_{2}$ and $\mathrm{CO}$ obtained by varying the ratio of biomass and catalyst over $7.5 \% \mathrm{Ni} / \gamma-\mathrm{Al}_{2} \mathrm{O}_{3}$ catalysts. Reaction conditions: $T=820{ }^{\circ} \mathrm{C}$, steam $/$ biomass $=2.02$, biomass mass $=0.2 \mathrm{~g}$.

unnecessary to produce $\mathrm{H}_{2}$-rich syngas.

\subsection{Structure and catalytic activity of $\mathrm{MgO}-7.5 \% \mathrm{Ni} / \gamma-\mathrm{Al}_{2} \mathrm{O}_{3}$ catalysts with different $\mathrm{MgO}$ contents}

$\mathrm{MgO}$ was doped into the $7.5 \% \mathrm{Ni} / \gamma-\mathrm{Al}_{2} \mathrm{O}_{3}$ catalyst to improve the catalytic activity of the water-gas shift reaction. XRD patterns of $\mathrm{MgO}-7.5 \% \mathrm{Ni} / \gamma-\mathrm{Al}_{2} \mathrm{O}_{3}$ catalysts with different $\mathrm{MgO}$ contents and $1.0 \% \mathrm{MgO}-7.5 \% \mathrm{Ni} / \gamma-\mathrm{Al}_{2} \mathrm{O}_{3}$ catalyst reduced in $\mathrm{H}_{2}$ at $700{ }^{\circ} \mathrm{C}$ for $3 \mathrm{~h}$ are shown in Fig. 6. No MgO diffraction peak was observed over all the samples. Nor were these catalysts observed after reduction in $\mathrm{H}_{2}$ for $3 \mathrm{~h}$. This was attributed to the low content and high dispersion of $\mathrm{Mg}$ species in the catalysts.

Diffraction peaks from $\mathrm{NiO}$ were not observed for samples containing $0-1.5 \% \mathrm{MgO}$, but a $\mathrm{NiO}$ peak was seen when $\mathrm{MgO}$ content was increased to $2.0 \%$. This indicates that the dispersed $\mathrm{NiO}$ grains may aggregate and grow large enough for their diffraction peak to be observed when a suitable amount of MgO promoter is added [32].

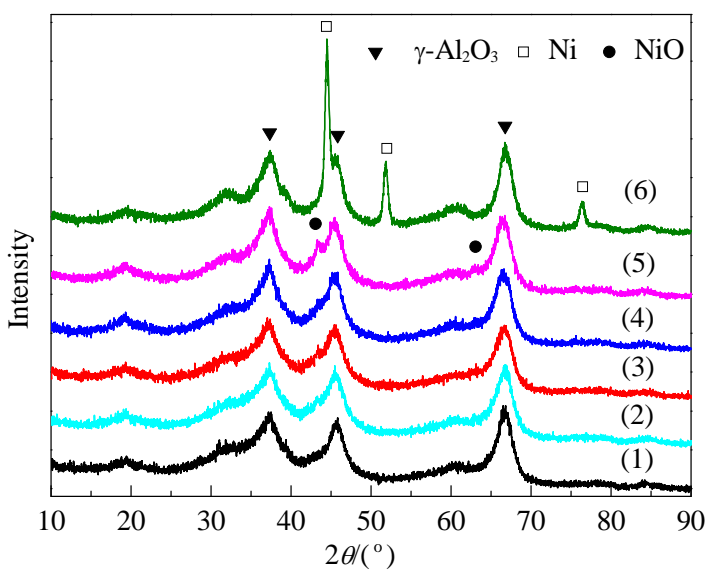

Fig. 6. $\mathrm{XRD}$ patterns of the $\mathrm{MgO}-\mathrm{Ni} / \gamma-\mathrm{Al}_{2} \mathrm{O}_{3}$ catalysts. (1) $7.5 \%$ $\mathrm{Ni} / \gamma-\mathrm{Al}_{2} \mathrm{O}_{3}$; (2) $0.5 \% \quad \mathrm{MgO}-7.5 \% \mathrm{Ni} / \gamma-\mathrm{Al}_{2} \mathrm{O}_{3}$; (3) $1.0 \% \mathrm{MgO}-7.5 \%$ $\mathrm{Ni} / \gamma-\mathrm{Al}_{2} \mathrm{O}_{3}$; (4) $1.5 \% \quad \mathrm{MgO}-7.5 \% \mathrm{Ni} / \gamma-\mathrm{Al}_{2} \mathrm{O}_{3}$; (5) $2.0 \% \mathrm{MgO}-7.5 \%$ $\mathrm{Ni} / \gamma-\mathrm{Al}_{2} \mathrm{O}_{3}$; (6) $1.0 \% \mathrm{MgO}-7.5 \% \mathrm{Ni} / \gamma-\mathrm{Al}_{2} \mathrm{O}_{3}$ reduced at $700{ }^{\circ} \mathrm{C}$ for $3 \mathrm{~h}$. 
Table 6

Pore structure parameters of $\mathrm{MgO}-7.5 \% \mathrm{Ni} / \gamma-\mathrm{Al}_{2} \mathrm{O}_{3}$ catalysts with different $\mathrm{MgO}$ contents.

\begin{tabular}{lccc}
\hline Catalyst & $\begin{array}{c}A_{\text {BET }} \\
\left(\mathrm{m}^{2} / \mathrm{g}\right)\end{array}$ & $\begin{array}{c}\text { Pore volume } \\
\left(\mathrm{cm}^{3} / \mathrm{g}\right)\end{array}$ & $\begin{array}{c}\text { Pore size } \\
(\mathrm{nm})\end{array}$ \\
\hline $7.5 \% \mathrm{Ni} / \gamma-\mathrm{Al}_{2} \mathrm{O}_{3}$ & 200.9 & 0.37 & 4.9 \\
$0.5 \% \mathrm{MgO}-7.5 \% \mathrm{Ni} / \gamma-\mathrm{Al}_{2} \mathrm{O}_{3}$ & 204.8 & 0.26 & 3.8 \\
$1.0 \% \mathrm{MgO}-7.5 \% \mathrm{Ni} / \gamma-\mathrm{Al}_{2} \mathrm{O}_{3}$ & 206.1 & 0.27 & 3.9 \\
$1.5 \% \mathrm{MgO}-7.5 \% \mathrm{Ni} / \gamma-\mathrm{Al}_{2} \mathrm{O}_{3}$ & 189.3 & 0.27 & 3.8 \\
$2.0 \% \mathrm{MgO}-7.5 \% \mathrm{Ni} \gamma-\mathrm{Al}_{2} \mathrm{O}_{3}$ & 163.5 & 0.29 & 3.9 \\
\hline
\end{tabular}

Table 6 shows the specific surface area and pore size distribution of the catalysts doped with various contents of MgO. The $1.0 \% \mathrm{MgO}-7.5 \% \mathrm{Ni} / \gamma-\mathrm{Al}_{2} \mathrm{O}_{3}$ catalyst had a larger surface area than the other catalysts, which may be caused by the dispersion of $\mathrm{MgO}$ over the surface of this sample. The specific surface area of the catalyst decreased from 206.1 to $163.5 \mathrm{~m}^{2} / \mathrm{g}$ when the mass fraction of $\mathrm{MgO}$ exceeded $1.0 \%$, and the average pore diameter also decreased from 4.9 to $3.8 \mathrm{~nm}$. These are attributed to the aggregation of $\mathrm{NiO}$ and the extra $\mathrm{MgO}$ grains entering into the pores of $7.5 \% \mathrm{Ni} / \gamma-\mathrm{Al}_{2} \mathrm{O}_{3}$ to decrease pore diameter.

The gas products and $\mathrm{H}_{2}$ yield from biomass gasification over $\mathrm{MgO}-7.5 \% \mathrm{Ni} / \gamma-\mathrm{Al}_{2} \mathrm{O}_{3}$ catalysts with different $\mathrm{MgO}$ contents are presented in Table 7. Doping with $\mathrm{MgO}$ resulted in production of $\mathrm{CO}_{2}$ over $7.5 \% \mathrm{Ni} / \gamma-\mathrm{Al}_{2} \mathrm{O}_{3}$. This was attributed to the water-gas shift reaction: $\mathrm{CO}+\mathrm{H}_{2} \mathrm{O}=\mathrm{CO}_{2}+\mathrm{H}_{2}, \Delta H=-41.1$ $\mathrm{kJ} / \mathrm{mol}$.

The volume content of $\mathrm{CO}_{2}$ decreased as the content of $\mathrm{MgO}$ increased. This suggests that MgO participated in the adsorption reaction of $\mathrm{CO}_{2}$, which has been well-documented by Florin et al. [33]. Furthermore, the presence of MgO may cause the Gibbs free energy of the water-gas shift reaction to decrease due to the absorption of $\mathrm{CO}_{2}$. In other words, the yield and volume content of $\mathrm{H}_{2}$ could be improved by the water-gas reaction. Table 7 shows that the yield of $\mathrm{H}_{2}$ increased from 1071.3 to $1194.6 \mathrm{ml} / \mathrm{g}$ as the content of $\mathrm{MgO}$ increased from 0 to $1.0 \%$, and the volume content of $\mathrm{H}_{2}$ increased from $33.1 \%$ to $48.9 \%$. At the same time, the volume content of $\mathrm{CO}$ decreased from $23.2 \%$ to $12.4 \%$. This change in volume content was much larger than that of $\mathrm{H}_{2}$, which may be related to the formation of $\mathrm{MgCO}_{3}$ in the water-gas shift reaction. Subsequently, the $\mathrm{H}_{2} / \mathrm{CO}$ ratio increased sharply from 1.4 to 3.9 , revealing the optimum conditions to produce $\mathrm{H}_{2}$-rich syngas.

Once the $\mathrm{MgO}$ content exceeded $1.0 \%$, the $\mathrm{H}_{2}$ yield decreased to $1163.2 \mathrm{ml} / \mathrm{g}$, and the volume content of $\mathrm{CO}$ in-

Table 7

Gas products formed over $\mathrm{MgO}-7.5 \% \mathrm{Ni} / \gamma-\mathrm{Al}_{2} \mathrm{O}_{3}$ catalysts with different MgO contents.

\begin{tabular}{|c|c|c|c|c|c|}
\hline \multirow{2}{*}{ Catalyst } & \multicolumn{3}{|c|}{ Volume contents (\%) } & \multirow{2}{*}{$\begin{array}{c}\mathrm{H}_{2} / \mathrm{CO} \\
\text { ratio } \\
\end{array}$} & \multirow{2}{*}{$\begin{array}{c}\mathrm{H}_{2} \text { yield } \\
(\mathrm{ml} / \mathrm{g})\end{array}$} \\
\hline & $\mathrm{H}_{2}$ & $\mathrm{CO}$ & $\mathrm{CO}_{2}$ & & \\
\hline $7.5 \% \mathrm{Ni} / \gamma-\mathrm{Al}_{2} \mathrm{O}_{3}$ & 33.1 & 23.2 & - & 1.4 & 1071.3 \\
\hline $0.5 \% \mathrm{MgO}-7.5 \% \mathrm{Ni} / \gamma-\mathrm{Al}_{2} \mathrm{O}_{3}$ & 45.4 & 16.7 & 15.2 & 2.7 & 1180.7 \\
\hline $1.0 \% \mathrm{MgO}-7.5 \% \mathrm{Ni} / \gamma-\mathrm{Al}_{2} \mathrm{O}_{3}$ & 48.9 & 12.4 & 14.3 & 3.9 & 1194.6 \\
\hline $1.5 \% \mathrm{MgO}-7.5 \% \mathrm{Ni} / \gamma-\mathrm{Al}_{2} \mathrm{O}_{3}$ & 46.6 & 13.5 & 13.7 & 3.6 & 1182.5 \\
\hline $2.0 \% \mathrm{MgO}-7.5 \% \mathrm{Ni} / \gamma-\mathrm{Al}_{2} \mathrm{O}_{3}$ & 44.3 & 15.3 & 12.5 & 2.9 & 1163.2 \\
\hline
\end{tabular}

Reaction conditions: $T=820^{\circ} \mathrm{C}$, steam/biomass $=2.02$, biomass mass $=$ $0.2 \mathrm{~g}$, biomass $/$ catalyst $=5 / 1$. creased from $12.4 \%$ to $15.3 \%$. This decrease in volume content is related to the decrease of the specific surface area of the catalysts. Therefore, excessive $\mathrm{MgO}$ doped in $7.5 \% \mathrm{Ni} / \gamma-\mathrm{Al}_{2} \mathrm{O}_{3}$ did not benefit the catalytic steam reforming reaction to produce $\mathrm{H}_{2}$-rich syngas.

The positive direction of the water-gas shift reaction can improve the $\mathrm{H}_{2}$ yield and volume content of gas product in the studied system. As a result, an increase of temperature hinders this exothermic reaction because its Gibbs free energy gradually turns positive, so the reaction is suppressed. According to thermodynamics, a suitable increase of the partial pressure of steam and decrease of the concentration of $\mathrm{CO}_{2}$ during the reaction could lower the Gibbs free energy of the system, which should help to improve $\mathrm{H}_{2}$ yield. Calcium and magnesium oxides, and therefore pre-calcined dolomite, can readily adsorb steam and $\mathrm{CO}_{2}$ from air. It has also been demonstrated that for metal-CaO interactions (as detected for iron), kinetic limitations are less important than the case of metal-MgO interactions (as reported for nickel), revealing the role of free $\mathrm{MgO}$ in promoting $\mathrm{CO}_{2}$ diffusion through the porous sorbent particles [34]. The highest amount of $\mathrm{H}_{2}$ production was achieved when nanosized $\mathrm{MgO}$ was used, and at the same time, a significantly higher amount of $\mathrm{CO}_{2}$ was released compared with the other catalysts. Therefore, $\mathrm{MgO}$ can be used as a promoter to enhance $\mathrm{H}_{2}$ production from biomass.

\section{Conclusions}

Various Ni-based catalysts with different supports and contents of MgO promoter were prepared. The maximum yield of $\mathrm{H}_{2}$ was achieved over a $7.5 \% \mathrm{Ni} / \gamma-\mathrm{Al}_{2} \mathrm{O}_{3}$ catalyst. Addition of $\mathrm{MgO}$ increased the yield of $\mathrm{H}_{2}$ and improved the product distribution and quality of the syngas from steam reforming of rice straw to $\mathrm{H}_{2}$-rich syngas, as well as decreasing the $\mathrm{CO}$ content in the syngas. MgO not only played the role of active catalytic component for the water-gas shift reaction but also behaved as an enhancer during catalytic steam reforming of rice straw. The ratio of $\mathrm{H}_{2}$ to $\mathrm{CO}$ reached $1.4: 1$ and the $\mathrm{H}_{2}$ yield was 1071.3 $\mathrm{ml} / \mathrm{g}$ over $7.5 \% \mathrm{Ni} / \gamma-\mathrm{Al}_{2} \mathrm{O}_{3}$ catalyst at $820{ }^{\circ} \mathrm{C}$. After doping with $1.0 \% \mathrm{MgO}$, these parameters reached 3.9:1 and $1194.6 \mathrm{ml} / \mathrm{g}$, respectively.

\section{References}

[1] Han L J, Yan Q J, Liu X Y, Hu J Y. Transcation of the Chinese Society of Agricultural Engineering (韩鲁佳, 问巧娟, 刘向阳, 胡金有. 农 业工程学报), 2002, 18(3): 87

[2] Lü P M, Chang J, Xiong Z H, Wu C Z, Chen Y. Coal Conversion (吕鹏 梅, 常杰, 熊祖鸿, 吴创之, 陈勇. 煤炭转化), 2002, 25(3): 32

[3] Lü P M, Chang J, Fu Y, Wang T J, Wu C Z, Chen Y, Zhu J X. Acta Energiae Solaris Sinica (吕鹏梅, 常杰, 付严, 王铁军, 吴创之, 陈勇, 祝京旭. 太阳能学报), 2004, 25(6): 769

[4] Devi L, Ptasinski K J, Janssen F J J G. Biomass Bioenergy, 2003, 24 : 125

[5] Corella J, Sanz A. Fuel Process Technol, 2005, 86: 1021

[6] Rapagna S, Provendier H, Petit C, Kiennemann A, Foscolo P U. Biomass Bioenergy, 2002, 22: 377

[7] Hu G, Xu S P, Liu S Q. Chemistry and Industry of Forest Products (胡 


\section{Graphical Abstract}

Chin. J. Catal., 2013, 34: 1462-1468 doi: 10.1016/S1872-2067(12)60618-4

\section{Catalytic steam reforming of rice straw biomass to hydrogen-rich syngas over Ni-based catalysts}

LI Qingyuan, JI Shengfu*, HU Jinyong, JIANG Sai

Beijing University of Chemical Technology

A series of supported Ni-based catalysts were prepared and used for steam reforming of rice straw biomass to hydrogen-rich syngas. A $1.0 \% \mathrm{MgO}-7.5 \%$ $\mathrm{Ni} / \gamma-\mathrm{Al}_{2} \mathrm{O}_{3}$ catalyst exhibited the highest catalytic activity of the series.

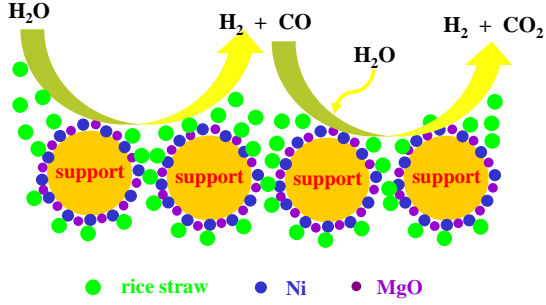

Supported Ni-based catalysts
冠, 徐绍平, 刘淑琴. 林产化学与工业), 2005, 25 (S1): 161

[8] Hashemnejad S M, Parvari M. Chin J Catal (催化学报), 2011, 32: 273

[9] Li D L, Nakagawa Y, Tomishige K. Chin J Catal (催化学报), 2012, 33: 583

[10] Li C, Hirabayashi D, Suzuki K. Fuel Process Technol, 2009, 90: 790

[11] Kimura T, Miyazawa T, Nishikawa J, Kado S, Okumura K, Miyao T, Naito S, Kunimorik K, Tomishige K. Appl Catal B, 2006, 68: 160

[12] Li X, Yang X Z, Tang H D, Liu H Z. Chin J Catal (李霞, 杨霞珍, 唐浩 东, 刘化章. 催化学报), 2011, 32: 1400

[13] Güell B M, da Silva I M T, Seshan K, Lefferts L. Appl Catal B, 2009, 88: 59

[14] Wang T J, Chang J, Lü P M. Energy Fuels, 2005, 19: 637

[15] Nakamura K, Miyazawa T, Sakurai T, Miyao T, Naito S, Begum N, Kunimori K, Tomishige K. Appl Catal B, 2009, 86: 36

[16] Jiang J C, Ying H, Dai W D, Zhang J P, Liu S C, Gao Y W, Jin C. Acta Energiae Solaris Sinica (蒋建春, 应浩, 戴伟娣, 张进平, 刘石彩, 高一苇, 金淳. 太阳能学报), 2004, 25: 678

[17] Umeki K, Namioka T, Yoshikawa K. Fuel Process Technol, 2012, 94: 53

[18] Cao L Y, Jia Z G, Ji S F, Hu J Y.J Nat Gas Chem, 2011, 20: 377

[19] Zhao M, Florin N H, Harris A T. Appl Catal B, 2009, 92: 185

[20] Xiao X B, Meng X L, Le D D, Takarada T. Bioresour Technol, 2011,
102: 1975

[21] Chaudhari S T, Dalai A K, Bakhshi N N. Energy Fuels, 2003, 17: 1062

[22] Zhang Y H, Xiong G X, Yang W S, Sheng S S. J Nat Gas Chem, 2000, 9: 175

[23] Li G H, Hu L J, Hill J M. Appl Catal A, 2006, 301: 16

[24] Wang X X, Wang X G, Shang X F, Nie W X, Zou X J, Lu X G, Ding W Z. Chin J Catal (王新星, 汪学广, 尚兴付, 聂望欣, 邹秀晶, 鲁雄钢, 丁伟中. 催化学报), 2012, 33: 1176

[25] Yan F, Luo S Y, Hu Z Q Xiao B, Cheng G. Bioresour Technol, 2010, 101: 5633

[26] Wu C F, Wang L Z, Williams P T, Shi J, Huang J. Appl Catal B, 2011, 108-109: 6

[27] Song Y Q Liu H M, Liu S Q, He D H. Energy Fuels, 2009, 23: 1925

[28] Evans R J, Milne T A. Energy Fuels, 1987, 1: 123

[29] Wooren J B, Seeman J I, Hajaligol M R. Energy Fuels, 2004,18: 1

[30] de Jong W, Pirone A, Wojtowicz M A. Fuel, 2003, 82: 1139

[31] Yue B H, Wang X G, Ai X P, Yang J, Li L, Lu X G, Ding W Z. Fuel Process Technol, 2010, 91: 1098

[32] Jeong H, Kim K I, Kim D, Song I K. J Mol Catal A, 2006, 246: 43

[33] Florin N H, Blamey J, Fennell P S. Energy Fuels, 2010, 24: 4598

[34] Felice L D, Courson C, Foscolo P U, Kiennemann A. Int J Hydrogen Energy, 2011, 36: 5296

\section{镍基催化剂上稻草水蒸气重整制富氢合成气 \\ 李庆远，季生福，胡金勇，蒋 赛 北京化工大学化工资源有效利用国家重点实验室, 北京100029}

摘要: 采用浸渍法制备了 $\mathrm{SiO}_{2}, \gamma-\mathrm{Al}_{2} \mathrm{O}_{3}, \mathrm{CaO}$ 和 $\mathrm{TiO}_{2}$ 负载的 $\mathrm{Ni}$ 催化剂, 以及不同 $\mathrm{MgO}$ 含量的 $\mathrm{MgO}-7.5 \% \mathrm{Ni} / \gamma-\mathrm{Al}_{2} \mathrm{O}_{3}$ 催化剂, 利用X射 线衍射和 $\mathrm{N}_{2}$ 吸附-脱附技术表征了催化剂的结构, 在固定床反应器上评价了它们在稻草水蒸气催化重整制合成气反应中的催化性 能, 考察了反应条件对催化剂性能的影响. 结果表明, 以 $\gamma-\mathrm{Al}_{2} \mathrm{O}_{3}$ 为载体时 $\mathrm{Ni}$ 催化剂活性最高, 其中 $7.5 \% \mathrm{Ni} / \gamma-\mathrm{Al}_{2} \mathrm{O}_{3}$ 催化剂的 $\mathrm{H}_{2}$ 收 率可达 $1071.3 \mathrm{ml} / \mathrm{g}, \mathrm{H}_{2}: \mathrm{CO}$ 的体积比为1.4:1; 同时, $\mathrm{MgO}$ 的添加进一步提高了该催化剂的性能, 当 $\mathrm{MgO}$ 含量为1.0\%时, $\mathrm{H}_{2}$ 收率可达 $1194.6 \mathrm{ml} / \mathrm{g}, \mathrm{H}_{2}$ : $\mathrm{CO}$ 体积比可达 3.9:1. 可见MgO的加入促进了 $\mathrm{Ni}$ 基催化剂上稻草水蒸气催化重整制合成气反应的进行, 同时使得 合成气中CO发生水-汽转换反应, 从而大大提高了合成气中 $\mathrm{H}_{2}$ 含量.

关键词: 镍基催化剂; 稻草; 水蒸气重整; 合成气; 氢气

收稿日期: 2012-12-29. 接受日期: 2013-05-16. 出版日期: 2013-07-20.

*通讯联系人. 电话/传真: (010)64419619; 电子信箱: jisf@mail.buct.edu.cn

基金来源：国家重点基础研究发展计划(973计划, 2005CB221405); 国家高技术研究发展计划(863计划, 2006AA10Z425).

本文的英文电子版由Elsevier出版社在ScienceDirect上出版(http://www.sciencedirect.com/science/journal/18722067). 